\title{
Kinetics of the Immune Response of Rabbits to Lower Trypanosomatidae Antigens
}

\author{
By ELLEN S. VITETTA AND HELENE N. GUTTMAN \\ Department of Biology, \\ University College and the Graduate School of Arts and Sciences, \\ New York University, Bronx, N.Y., I0453, U.S.A.
}

(Accepted for publication I July 1967)

SUMMARY

Experiments tracing the kinetics of the hyperimmune response in rabbits injected with several lower trypanosomatids (Crithidia fasciculata (Anopheles strain), C. fasciculata (Culex strain, Wallace isolate), C. fasciculata (Culex strain, Nöller isolate), Crithidia sp. from Euryophthalmus davisi, Blastocrithidia leptocoridis, Leptomonas sp. from Dysdercus and L. mirabilis) mixed with Freund's complete adjuvant revealed a slow increase in homologous agglutinating titre, followed by a lasting plateau titre. Cross-reactions tested at various homologous titres showed that cross-reacting specificity increased as the titre increased. At peak agglutinating titre, sera were at their maximum specificity and remained like that during the lasting plateau period. Precipitins appeared before agglutinins and faded as the homologous agglutinating titres increased. Precipitins, in contrast to agglutinins, were specific even when the agglutinating titres were low and non-specific. By analogy with work done by other investigators on identification of serum fractions associated with non-protozoan antigens in which immune kinetics, globulin generation, or globulin specificity were traced, we suggest that the early-appearing nonspecific agglutinins may be composed of $19 \mathrm{~S}$ globulins and the late- appearing specific agglutinins and specific precipitins may be composed of $7 \mathrm{~S}$ globulins.

\section{INTRODUCTION}

There have been only four reports in which relationships among the lower Trypanosomatidae have been traced by their immunological affinities (Clark, 1958; McGhee \& Hanson, 1963; Noguchi, 1926; Vitetta \& Guttman, 1967). Differences in the results of various investigators have led to conflicting statements about group relationships. Some examples are: (I $a$ ) within the genus Crithidia, all organisms isolated from hemipterons are more closely related immunologically to each other than are all organisms originally isolated from dipterons (McGhee \& Hanson, I963), or (I $b$ ) immunological relationships are independent of host-type (Vitetta \& Guttman, 1967); (2a) Culex and Anopheles strains of Crithidia fasciculata are identical (Noguchi, 1926), (2b) Anopheles and only one but not another Culex strain of C. fasciculata are identical (Clark, 1958), (2c) from immunological and biochemical evidence, the Anopheles and both Culex strains of C. fasciculata are distinct (Vitetta \& Guttman, 1967).

In only one of the aforementioned reports (Vitetta \& Guttman, 1967) was there used the combination of (a) an antibody-generating system said to produce the most physico-chemically homogeneous antibodies (Crowle, 1963; Kabat \& Mayer, 196I); 
(b) high-titre antisera (equal to or greater than I/2560) for testing all cross-sections; (c) routine inactivation of complement. Since Vitetta \& Guttman (1967) prepared antibodies by a method which included the use of Freund's complete adjuvant (a mixture which not only enhances production of high-titre antiserum but also lengthens the time required before peak titre is reached), we report here on the kinetic tracking of antibody production during the course of the hyperimmune response in rabbits to antigens mixed the Freund's adjuvant and on cross-reactivity of sera before, at, and after peak homologous titre.

\section{METHODS}

The organisms used as antigens in these studies were Crithidia fasciculata (Anopheles strain) ATCC II745; C. fasciculata (Culex strain, Wallace isolate) ATCC 12857; C. fasciculata (Culex strain, Nöller isolate) ATCC 12858; C. luciliae ATCC 14765; C. oncopelti (with endosymbiote) ATCC 12982; Crithidia sp. from Euryophthalmus davisi, ATCC 14766; Blastocrithidia leptocoridis; Leptomonas sp. from Dysdercus suturellus, and L. mirabilis.

Methods already reported (Vitetta \& Guttman, 1967) were used for preparation of antigens, mixture of antigen with Freund's complete adjuvant for hyper-immunization, generation of antibodies in rabbits and procedures for agglutination tests.

Precipitin tests. All precipitin tests were done in Ouchterlony double diffusion plates (Hyland Laboratories, Los Angeles, California). Disrupted-cell antigen suspensions were placed in the central well and undiluted sera placed in the peripheral wells. The plates were covered with their own plastic lids to prevent drying and were incubated at room temperature $\left(25^{\circ}\right)$ for $24 \mathrm{hr}$. They were then washed in cold $0.85 \%(\mathrm{w} / \mathrm{v})$ $\mathrm{NaCl}$ solution for $24-48 \mathrm{hr}$ to remove excess antigen and serum and then scanned at $\times 100$ magnification for precipitin lines. The numbers and intensity of precipitin lines were recorded for each antiserum challenged with homologous antigen. Crossreactions were determined by using sera which showed the most intense and/or greatest number of lines with homologous antigen.

\section{RESULTS}

The usual pattern of agglutinating hyperimmune response in rabbits following injection of antigen mixed in Freund's complete adjuvant was an increase in titre beginning I-20 days after the last antigen injection and continuing to rise for I0-40 more days (Fig. I). After peak titre was reached, there was a slight decrease in titre and persistence of the agglutinating response at this plateau for at least 140 days (experiments were terminated at that time). Such a pattern of slow rise of titre and maintenance of high titre is typical for adjuvant-injected animals (Uchitel \& Khasman, 1965). The one exception to formation of a stable agglutinating titre in our experiments was with one Crithidia sp. from Euryophthalmus antiserum which reached a rather low peak titre and then decreased rapidly to zero (Figure 2).

For all antisera tested, there was a distinct pattern of relationship between precipitins and agglutinins which was unrelated to either the particular antigen used or to the type of cell preparation (i.e. whole or disrupted cells). Precipitins appeared before agglutinins and usually were most apparent when agglutinating titres were still low (Table I). 
Although all precipitating responses declined as the agglutinating titres increased (Table I), the precise timing was not constant: precipitins disappeared (a) before peak agglutinating titre in two antisera (anti-C. fasciculata (Culex strain) serum and anti-Leptomonas sp. from Dysdercus suturellus serum), (b) slightly after peak agglutinating titre in three antisera (two $C$. fasciculata (Culex strain) sera and anti- $B$. leptocoridis serum), and (c) persisted in two other antisera (anti-Leptomonas sp. from Dysdercus suturellus serum and anti-L. mirabilis serum).

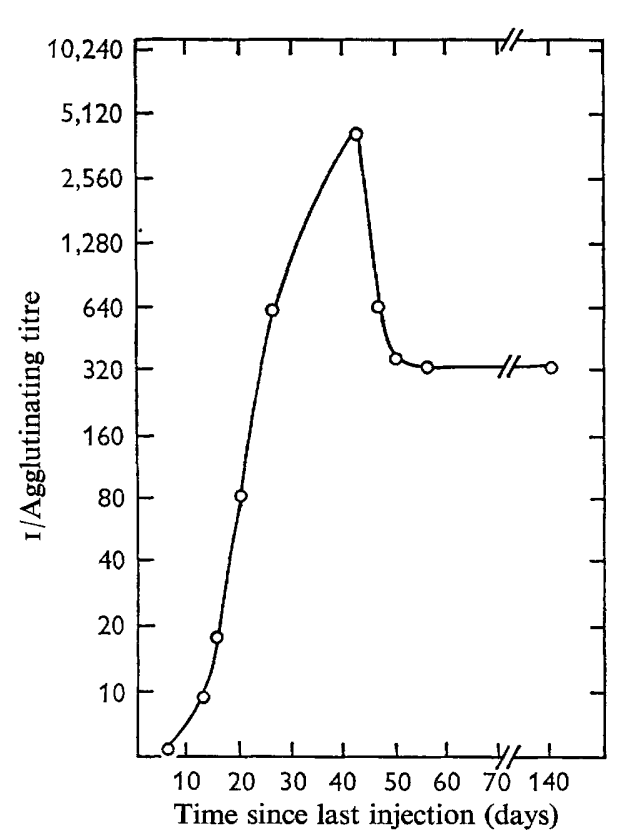

Fig. I

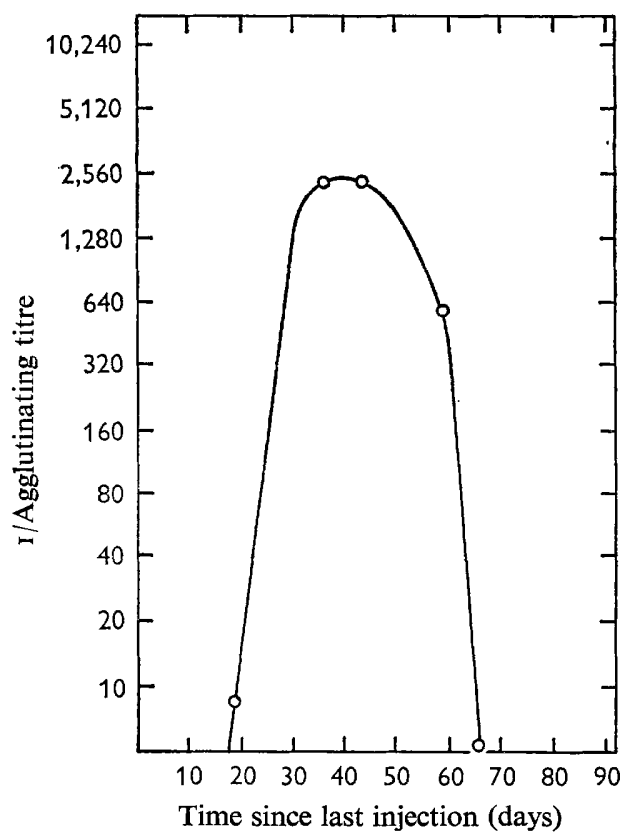

Fig. 2

Fig. I. Kinetics of antibody generation to whole Crithidia fasciculata (Culex strain, Wallace isolate). Similar kinetics were observed in 15 other antisera generated against lower trypanosomatid antigens.

Fig. 2. Kinetics of antibody generation to disrupted organisms of a Crithidia sp. (from Euryophthalmus davisi).

In our previous study (Vitetta \& Guttman, 1967) all agglutinating cross-reactions were determined at peak or plateau homologous titre. We now show (Table 2) the striking decrease in agglutinating cross-reactions concomitant with increase in homologous titre. For antisera to whole or disrupted C. fasciculata (Culex strain, Wallace isolate), whole Leptomonas sp. from Dysdercus suturellus, or whole B. leptocoridis, four series in which cross-reactions were followed during the whole sequence of rising, plateau and decreasing titre (Table 2), antibody specificity increased as the homologous titre increased. This specificity was maintained and strengthened at peak and post-peak homologous titres. Although there were insufficient data to follow the development of cross-reacting antibody specificity for other organisms, some generalizations can be made:

(I) At very low agglutinating titres, agglutinating cross-reactions were high and non-specific (Table $3 a$ ). 
(2) Cross-reactivity declined as the homologous agglutinating titre neared a peak, i.e. antibody specificity increased with titre (Table 2).

(3) At peak titre, plateau titre, and decreasing titre after peak, agglutinating crossreactions remained constantly specific, despite the changes in homologous titre (Table $3 b$ ).

In contrast to lack of specificity of agglutinating antibodies, precipitating cross-

Table I. Kinetics of the production of agglutinating and precipitating antibodies

\begin{tabular}{|c|c|c|c|c|}
\hline Antiserum to & $\begin{array}{l}\text { Rabbit } \\
\text { no. }\end{array}$ & $\begin{array}{l}\text { Days since } \\
\text { last } \\
\text { injection }\end{array}$ & $\begin{array}{l}\text { Agglutinating } \\
\text { titre }\end{array}$ & $\begin{array}{c}\text { Precipitating } \\
\text { lines } \\
\text { (no. and intensity) }\end{array}$ \\
\hline \multirow[t]{3}{*}{$\begin{array}{l}\text { C. fasciculata } \\
\text { (Culex, Wallace) }\end{array}$} & $\mathbf{I}$ & $\begin{array}{r}12 \\
28 \\
40 \\
140\end{array}$ & $\begin{array}{l}I / 40 \\
I / I 280 \\
I / 5 I 20-I / 10240 \\
I / 5 I 20\end{array}$ & $\begin{array}{l}\text { I faint } \\
\text { I faint } \\
\text { I faint } \\
\text { o }\end{array}$ \\
\hline & 2 & $\begin{array}{l}15 \\
20 \\
30 \\
32 \\
40 \\
50\end{array}$ & $\begin{array}{l}0 \\
0 \\
1 / 1280 \\
1 / 5120 \\
I / 1280 \\
I / 1280\end{array}$ & $\begin{array}{l}\text { I faint } \\
\text { I faint } \\
\text { I faint } \\
\text { I faint } \\
0\end{array}$ \\
\hline & 3 & $\begin{array}{r}8 \\
14 \\
21 \\
27 \\
36\end{array}$ & $\begin{array}{l}I / 1 \\
I / 10 \\
1 / 80 \\
I / 640 \\
I / 2560\end{array}$ & $\begin{array}{l}\text { I sharp } \\
\text { I faint } \\
\text { I faint } \\
\text { I faint } \\
0\end{array}$ \\
\hline \multirow[t]{2}{*}{$\begin{array}{l}\text { Leptomonas from_Dysdercus } \\
\text { suturellus }\end{array}$} & I & $\begin{array}{l}10 \\
14 \\
21 \\
27 \\
30 \\
37 \\
40\end{array}$ & $\begin{array}{l}0 \\
0 \\
1 / 80-1 / 160 \\
I / 320 \\
I / 1280 \\
I / 2560-1 / 5120 \\
1 / 5120\end{array}$ & $\begin{array}{l}2 \text { sharp } \\
2 \text { faint } \\
\text { I sharp } \\
\text { I sharp } \\
\text { I sharp } \\
\text { I faint } \\
\text { I faint }\end{array}$ \\
\hline & 2 & $\begin{array}{l}10 \\
14 \\
21 \\
30\end{array}$ & $\begin{array}{l}0 \\
0 \\
0 \\
1 / 320\end{array}$ & $\begin{array}{l}2 \text { sharp } \\
\text { I sharp } \\
\text { I faint } \\
\text { o }\end{array}$ \\
\hline B. leptocoridis & & $\begin{array}{r}5 \\
10 \\
15 \\
25 \\
30 \\
48 \\
55 \\
110 \\
120 \\
140\end{array}$ & $\begin{array}{l}0 \\
0 \\
I / 640-I / I 280 \\
I / 640-I / I 280 \\
I / 2560 \\
I / 5120 \\
I / I 0240 \\
I / 2560 \\
I / 2560 \\
I / I 280\end{array}$ & $\begin{array}{l}2 \text { very sharp } \\
2 \text { sharp } \\
2 \text { faint } \\
\text { I faint } \\
\text { I faint } \\
\text { I faint } \\
\text { I faint } \\
\text { I faint } \\
\text { I faint } \\
0\end{array}$ \\
\hline L. mirabilis & & $\begin{array}{r}5 \\
10 \\
20 \\
30 \\
40 \\
56 \\
63 \\
69\end{array}$ & $\begin{array}{l}0 \\
0 \\
1 / 640-1 / 1280 \\
1 / 1280 \\
1 / 10240 \\
1 / 10240 \\
1 / 5120 \\
1 / 2560\end{array}$ & $\begin{array}{l}2 \text { sharp } \\
2 \text { sharp } \\
2 \text { faint } \\
2 \text { faint } \\
\text { I faint } \\
\text { I faint } \\
\text { I faint } \\
\text { I faint }\end{array}$ \\
\hline
\end{tabular}


reacting antibodies are very specific when the homologous agglutinating titre is low and remain specific during the course of the precipitating immune response (Table 4; see also Vitetta \& Guttman, 1967).

Table 2. A comparison of percentage agglutinating cross-reaction at indicated homologous agglutinating titres

Antiserum to

Whole C. fasciculata

(Culex strain,

Wallace isolate)

Disrupted

C. fasciculata (Culex strain, Wallace isolate)

Whole Leptomonas from Dysdercus suturellus

Whole Blastocrithidia leptocoridis
Whole antigen

C. from Euryophthalmus davisi

L. from Dysdercus suturellus

L. mirabilis

B. leptocoridis

C. from Euryophthalmus davisi

L. from Dysdercus suturellus

L. mirabilis

B. leptocoridis

C. from Euryophthalmus davisi

C. fasciculata (Culex strain, Wallace isolate)

L. mirabilis

B. leptocoridis

Homologous agglutination titre at which cross-reactions were done. Rising titres

Postpeak $\overbrace{I / 20 I / 640} I / 1280 I / 2560 \quad I / 5120 I / 10240 \quad I / 320$

$\begin{array}{rrrrrrr}100 & 100 & . & . & 25^{*} & . & 25 \\ 100 & 50 & . & . & 25^{*} & . & 50 \\ 100 & 100 & . & . & 100^{*} & . & 50 \\ 100 & 100 & . & . & 100^{*} & \cdot & 25\end{array}$

Crithidia sp. from Euryophthalmus davisi C. fasciculata (Culex strain, Wallace isolate) Leptomonas sp. from Dysdercus suturellus L. mirabilis

$\begin{array}{crrrrr}. & 100 & . & 12 & 12 * & . \\ . & 100 & . & 25 & 25^{*} & . \\ . & 100 & . & 50 & 50^{*} & . \\ 100 & 50 & . & 12 & 12^{*} & . \\ 100 & 100 & . & 12 * & . & . \\ 100 & 100 & . & 25^{*} & . & . \\ 100 & 100 & . & 50^{*} & . & . \\ & 100 & 100 & 25 & 12^{*} & . \\ \text { late) } & 100 & 100 & 50 & 25^{*} & . \\ & 100 & 50 & 50 & 50^{*} & . \\ & 100 & 50 & 50 & 50^{*} & .\end{array}$

* Peak homologous agglutinating titre.

Table $3 a$. Percentage agglutinating cross-reaction at low (pre-peak) homologous agglutinating titres

Titre when

cross-

Antiserum to

Peak titre

reactions

Whole C. fasciculata

I/5120-I/10240 I/I 280

(Culex strain,

Nöller isolate)

Antigen

$\%$

cross-

reaction

C. fasciculata (Culex strain, Wallace isolate) 100

C. fasciculata (Anopheles strain) 100

C. from Euryophthalmus davisi

C. luciliae

C. oncopelti (endosymbiote infected)

L. from Dysdercus suturellus

C. fasciculata (Anopheles strain)

C. fasciculata (Culex strain, Wallace isolate)

$L$. from Dysdercus suturellus

C. fasciculata (Culex strain, Nöller isolate)

C. luciliae

C. oncopelti (endosymbiote infected)

C. fasciculata (Anopheles strain)

C. fasciculata (Culex strain, Wallace isolate)

C. from Euryophthalmus davisi

C. fasciculata (Culex strain, Nöller isolate)

L. from Dysdercus suturellus

C. oncopelti (endosymbiote infected
100

100

100

25

100

100

100

IOO

I00

IOO

IOO

100

50

50

IOO

50 
Table $3 b$. Percent agglutinating cross-reaction at peak and post-peak homologous agglutinating titres

Whole C. fasciculata (Cule strain, Wallace isolate)

\begin{tabular}{|c|c|c|}
\hline Antiserum to & $\begin{array}{c}\text { Peak } \\
\text { titre }\end{array}$ & $\begin{array}{l}\text { Titre when } \\
\text { cross- } \\
\text { reactions } \\
\text { tested }\end{array}$ \\
\hline C. fasciculata (Culex & $1 / 10240$ & I $/ 10240$ \\
\hline
\end{tabular}

Whole C. fasciculata

(Anopheles strain)
Disrupted C. fasciculata (Culex strain, Nöller isolate)

Disrupted C. fasciculata
(Culex strain, Wallace
isolate)

Disrupted C. from Euryophthalmus davisi

\author{
Disrupted $L$. from \\ Dysdercus suturellus
}

Disrupted L. mirabilis

.

$1 / 5120 \quad 1 / 5120$

$I / 5120 \quad I / 5120$

$1 / 2560 \quad 1 / 320$

$I / 2560 \quad$ I/ 640

I/5120- $1 / 5120$

$\mathrm{I} / 5120 \quad \mathrm{I} / 5 \mathrm{I} 20$

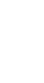

Antigen

C. fasciculata (Anopheles strain)

C. from Euryophthalmus davisi

C. fasciculata (Culex strain, Nöller isolate)

L. from Dysdercus suturellus

C. oncopelti (endosymbiote infected)

C. luciliae

C. fasciculata (Culex strain, Wallace isolate)

C. fasciculata (Anopheles strain)

C. from Euryophthalmus davisi

C. luciliae

C. oncopelti (endosymbiote infected)

$L$. from Dysdercus suturellus

C. fasciculata (Culex strain, Wallace isolate)

C. from Euryophthalmus davisi

$L$. from Dysdercus suturellus

C. fasciculata (Culex strain, Nöller isolate)

C. luciliae

C. oncopelti (endosymbiote infected) 50

C. fasciculata (Anopheles strain) $\quad$ I00

C. from Euryophthalmus davisi I2

C. fasciculata (Culex strain, Nöller isolate) 50

C. luciliae $\quad 25$

L. from Dysdercus suturellus 25

C. oncopelti (endosymbiote infected) 50

L. from Dysdercus suturellus $\quad$ I2

L. mirabilis $\quad 25$

B. leptocoridis

C. fasciculata (Culex strain, Wallace isolate) $\mathbf{2 5}$

C. fasciculata (Anopheles strain) 50

C. fasciculata (Culex strain, Wallace isolate) 25

C. from Euryophthalmus davisi 100

C. fasciculata (Culex strain, Nöller isolate) 25

C. luciliae $\quad 25$

C. oncopelti (endosymbiote infected) 25

C. fasciculata (Culex strain, Wallace isolate) 50

$L$. from Dysdercus suturellus $\quad 25$

B. leptocoridis $\quad 100$

C. from Euryophthalmus davisi $\quad 25$

\section{DISCUSSION}

Although it is clear that the specificity of precipitating antibodies was acquired early in the course of the immune response while the specificity of agglutinating antibodies was still changing in the direction of increased specificity during the same period (Tables 2,3 ), the biochemical events leading to the changes in specificity are not yet clear. Two possible explanations are: (i) there is an increasing modification of a particular class of antibody molecules as the titre rises; (ii) there is independent synthesis of different classes of antibody proteins each of which differs with respect to specificity and probably to gross molecular structure. 
It has now been established by numerous workers that at least two types of globulins are generated after primary inoculation with viral, bacterial, or foreign antigen. The first antibodies generated are $19 \mathrm{~S}$ globulins (gamma $\mathrm{M}$ or macroglobulins) which are later replaced by lighter $7 \mathrm{~S}$ globulins (gamma $\mathrm{G}$ or gamma globulins) (Bauer \& Stavitsky, I96I; Daniel, I965; Benedict, Brown \& Ayengar, 1962; Nisonoff \& Thorbecke, I964; Svehag \& Mandel, 1964). Normal and immune 7 S globulins contain

\section{Table 4. Precipitating cross-reactions between disrupted antigen and antisera against disrupted cells}

The experiments were done with sera which showed the most intense and/or greatest number of lines with homologous antigen.

\begin{tabular}{|c|c|c|c|c|c|}
\hline & \multicolumn{5}{|c|}{ Antigens } \\
\hline Antiserum to & $\begin{array}{l}\text { Crith } \\
\text { fasciculata } \\
\text { (Culex- } \\
\text { Wallace) }\end{array}$ & $\begin{array}{l}\text { dia sp. } \\
\text { from Eury- } \\
\text { ophthalmus } \\
\text { davisi }\end{array}$ & $\begin{array}{l}\text { Leptomonas } \\
\text { sp. from } \\
\text { Dysdercus } \\
\text { suturellus }\end{array}$ & mirabilis & $\begin{array}{c}\text { Blasto- } \\
\text { crithidia } \\
\text { Leptocoridis }\end{array}$ \\
\hline $\begin{array}{l}\text { lata } \\
\text { Vallace isolate) }\end{array}$ & + & - & - & - & - \\
\hline Euryophthalmus davisi & - & + & - & - & - \\
\hline from Dysdercus suturellus & - & - & + & - & - \\
\hline & - & - & - & + & - \\
\hline coridis & - & - & - & - & + \\
\hline
\end{tabular}

Crithidia fasciculato

(Culex strain, Wallace isolate)

Crithidia sp. from Euryophthalmus davisi

Leptomonas sp. from Dysdercus suturellus

L. mirabilis

Blastocrithidia leptocoridis two identical light (L) chains linked by disulphide bonds to two identical heavy $(\mathrm{H})$ chains (Edelman \& Benacerraf, r962; Edelman, Benacerraf \& Ovary, 1963; Edelman \& Gally, 1964; Nossal, Svenberg, Ada \& Austin, 1964; Fougereau \& Edelman, 1965). There are several alternative classes of $\mathbf{H}$ chains which can combine with $L$ chains to make the whole $7 \mathrm{~S}$ molecule (Potter, Apella \& Geisser, 1965). Antibody specificity is dependent upon the amino acid sequence at or near the two $\mathrm{H}$-L interaction sites (Almeida, Cinader \& Howatson, 1963; Buckley, Whitney \& Tanford, I963; Koshland \& Engelberger, 1963; Roholt, Onoue \& Pressman, I964; Metzger, Wofsy \& Singer, 1964; Roholt, Radzimski \& Pressman, I963; Titani \& Putnam, 1965; Whitney \& Tanford, 1965). The macroglobulin has a molecular weight of one million and contains the same $\mathrm{L}$ chains as does the globulin, but different $\mathbf{H}$ chains (Edelman \& Gally, I964; Nossal, Svenberg, Ada \& Austin, 1964). Since the gamma G globulin and gamma $\mathbf{M}$ macroglobulin have different primary structures, the macroglobulins are not merely polymers of smaller $7 \mathrm{~S}$ globulins (Onoue et al. 1965 ).

Fishman (196I) suggested that the $19 \mathrm{~S}$ and $7 \mathrm{~S}$ globulins are each synthesized by different plasma cells which are associated with the same antigen-engulfing macrophage. Nossal et al. (1964), on the other hand, postulated that during the course of the immune response, single maturing plasma cells switch from $19 \mathrm{~S}$ to $7 \mathrm{~S}$ globulin synthesis. Regardless of whether both ${ }_{19} \mathrm{~S}$ and $7 \mathrm{~S}$ globulins are made by the same or different cells in a competent tissue, the mechanism responsible for the switch-over from production of ${ }_{19} \mathrm{~S}$ to $7 \mathrm{~S}$ globulin in the antibody-synthesizing system as a whole is not yet clear. Some factors which influence this switch-over rate are as follow.

(a) The size of the antigen dose. When large doses of antigen are given to the antibody generating system, the time lapse between $19 \mathrm{~S}$ and $7 \mathrm{~S}$ globulin synthesis is decreased (Mellors \& Korngold, 1963; Uhr \& Finkelstein, I963; Uhr, 1964; Svehag \& Mandel, 1964), indicating that the antigen concentration activates the 
switch-over mechanism. In cases of these large antigen doses, the $19 \mathrm{~S}$ globulins are synthesized at a rapid rate, but are short lived while the $7 \mathrm{~S}$ globulins increase at a slower rate but endure (Mellors \& Korngold, I963; Uhr \& Finkelstein, 1963; Uhr, I964; Svehag \& Mandel, I964).

(b) Use of Freund's complete adjuvant. Adjuvant, which has been said to cause non-specific antibody synthesis (Freund et al. I948; John \& Gers1, r959; Uchitel \& Khasman, 1965), actually causes an increase in $19 \mathrm{~S}$ but not in $7 \mathrm{~S}$ globulin synthesis (Benedict, I965).

Both the aforementioned factors $(a)$ and $(b)$ would indicate that the I9S globulin is less specific than is the $7 \mathrm{~S}$ globulin. Indeed, it has been suggested by Onoue (Onoue et al. 1965) that since the macroglobulin has six binding sites per molecule as opposed to two for the $7 \mathrm{~S}$ globulin, it has greater (and perhaps more random) binding activity (Franklin \& Kunkel, I957; Korngold \& Van Leeuwen, 1957; Müller-Eberhard, Kunkel \& Franklin, 1956). Work with allergic individuals (Sehon, 1959) also indicates that the $19 \mathrm{~S}$ Globulin is less specific than is the $7 \mathrm{~S}$ globulin.

Unlike precipitating antibodies which are exclusively composed of $7 \mathrm{~S}$ globulin, agglutinating antibodies may be either $19 \mathrm{~S}$ or $7 \mathrm{~S}$ globulins (Benedict, 1965; Benedict, Brown \& Ayengar, 1962). Thus, it may be inferred from the previous discussion of specificity that precipitating antibodies are always specific, while agglutinating antibodies may be either specific or non-specific depending on whether they are composed of ${ }_{19} \mathrm{~S}$ (non-specific) or $7 \mathrm{~S}$ (specific) globulins.

Since in the experiments reported here we used large doses of antigen in Freund's complete adjuvant, it would be reasonable that, at the time of the first antiserum collection (3 weeks after the first injection), both ${ }_{19} \mathrm{~S}$ and ${ }_{7} \mathrm{~S}$ globulins were present in the antiserum, the former in high concentration and the latter in low concentration (since it was already 'late' with respect to generation of the first antibodies). Since precipitins are present only in the $7 \mathrm{~S}$ globulin fraction (Benedict, 1965 ) and because the $7 \mathrm{~S}$ globulin is specific (Benedict, 1965), all precipitins present when agglutinating titres are low should be specific, as indeed we have found them to be (Vitetta \& Guttman, 1967). Unlike precipitins, agglutinins are present in both the $19 \mathrm{~S}$ and ${ }_{7} \mathrm{~S}$ fractions (Benedict, 1965). At low agglutinating titres, the concentration of I9S globulin should be higher than that of the $7 \mathrm{~S}$ globulin, thus accounting for presence of non-specific agglutinins (Tables 2 and $3 a$ ). As the titre increases, the $7 \mathrm{~S}$ globulin concentration should increase (Benedict, 1965; Daniel, 1965; Mellors \& Korngold, I963), accounting for the more specific agglutinating cross-reactions which were observed (Table 2). By the time peak titre was reached, $19 \mathrm{~S}$ globulin synthesis should have ceased and $7 \mathrm{~S}$ globulins exclusively produced (Benedict, I965; Daniel, I965; Mellors \& Korngold, 1963), thus accounting for the high specificity of the crossreactions (Table $3 b$ ). Our preliminary results do indeed show such relationships between $19 \mathrm{~S}$ and $7 \mathrm{~S}$ globulins. The fading or complete disappearance of the precipitating reaction at high agglutinating titre (Table I) might be due to the masking of precipitins by non-precipitating antibody in the same globulin fraction (Gray, 1964). Accordingly, the detection of precipitins would depend on the ratio of precipitating to agglutinating antibody in the $7 \mathrm{~S}$ globulin fraction at any particular agglutinating titre. At plateau and post-peak titres, despite the changes in homologous titre (slowdown of $7 \mathrm{~S}$ globulin synthesis) the percentage cross-reaction should remain fairly constant, as indeed was observed (Table $3 b$ ). 
We have thus shown the importance of the use of high-titre serum which is at peak or post-peak homologous agglutinating titre for the determination of specific immunological affinities by means of agglutinating cross-reactions. It is therefore probable that earlier disagreements among different workers (Clark, I958; McGhee \& Hanson, 1963; Noguchi, 1926) about immunological affinities within the genus Trypanosomatidae may have been due to inadvertent failure to select peak or post-peak titre antisera for the most specific cross-reaction determinations.

This work was aided by grant AI-06530 from the U.S. Public Health Service.

\section{REFERENCES}

Almeida, J., Cinader, B. \& Howatson, A. (1963). The structure of antigen-antibody complexes. J. exp. Med. 118, 327.

Bauer, D. C. \& Stavitsky, S. B. (196I). On the different molecular forms of antibody synthesized by rabbits during the early response to a single injection of protein and cellular antigens. Proc. natn. Acad. Sci., U.S.A. 47, I667.

BENEDICT, A. A. (1965). Sensitivity of passive hemagglutination for assay of $7 \mathrm{~S}$ and $\mathrm{I9} S$ antibodies in primary rabbit anti-bovine serum albumin sera. Nature Lond. 206, 1368.

Benedict, A. A., Brown, R. J. \& Ayengar, R. (1962). Physical properties of antibodies to bovine serum albumin as demonstrated by hemagglutination. J. exp. Med. 115, 195.

BuCKLEY, C. E., Whitney, P. L. \& TANFORD, C. (1963). The unfolding and renaturation of a specific univalent antibody fragment. Proc. natn. Acad. Sci., U.S.A. 50, 827.

CLARK, JR., T. B. (1958). A comparative serological and morphological study of the family Trypanosomatidae Doflein, I90I. Doctoral thesis. University of Minnesota, U.S.A.

Crowle, A. J. (1963). Immunodiffusion. New York: Academic Press.

DANIEL, T. M. (1965). Observations on the antibody response of rabbits to mycobacterial antigens. J. Immunol. 95, 100.

Edelman, G. M. \& BenaCerraf, B. (I962). On structural and functional relations between antibodies and proteins of the gamma system. Proc. natn. Acad. Sci., U.S.A. 48, 1035.

Edelman, G. M., Benacerraf, B. \& Ovary, Z. (1963). Structure and specificity of guinea-pig $7 \mathrm{~S}$ antibodies. J. exp. Med. 118, 229.

Edelman, G. M. \& Gally, J. A. (I964). A model for the 7 S antibody molecule. Proc. natn. Acad. Sci., U.S.A. 51, 846.

Fishman, M. (196I). Antibody formation in vitro. J. exp. Med. 114, 837.

Fougereau, D. V. M. \& Edelman, G. M. (1965). Corroboration of recent models of the gamma immunoglobin molecule. J. exp. Med. 121, 373.

Franklin, E. C. \& Kunkel, H. G. (1957). Immunological differences between the I9S and $7 \mathrm{~S}$ components of normal human gamma globulin. J. Immunol. 78, I I.

Freund, J., Thompson, K. J., Hough, H. B., Sommer, H. E. \& Piscini, T. M. (1948). Antibody formation and sensitization with the aid of adjuvants. J. Immunol. 60, 383 .

Gray, D. F. (1964). Immunology. New York: American Elsevier Pub. Co. Inc.

John, C. \& GersL, T. (I959). Parental administration of oil as a factor stimulating antibody production. In Mechanisms of Antibody Production: Symposium Proceedings. New York: Academic Press.

Kabat, E. A. \& MAYeR, M. M. (196I). Experimental Immunochemistry. Illinois, U.S.A.: Chas. C. Thomas Publishing Co.

KoRngold, L. \& VAN LeeUwen, G. V. (I957). Macroglobulinemia II. Antisera specific for pathological macroglobulins. J. exp. Med. 106, 477 .

Koshland, M. E. \& Engelberger, F. N. (1963). Differences in the amino acid composition of two purified antibodies from the same rabbit. Proc. natn. Acad. Sci., U.S.A. 50,61.

MCGhee, R. B. \& HANson, W. L. (1963). The relationship of various crithidia as determined by serological reactions. J. Protozool. 10, 239.

Mellors, R. C. \& Korngold, L. (1963). The cellular origin of human immunoglobins. J. exp. Med. $118,387$.

Metzger, H., Wofsy, L. \& Singer, S. H. (1964). The participating of A and B polypeptide chains in the active sites of antibody molecules. Proc. natn. Acad. Sci., U.S.A. 51, 61 2.

Müller-Eberhard, H. J., Kunkel, H. G. \& Franklin, E. C. (1956). Two types of gamma globulin differing in carbohydrate content. Proc. Soc. exp. Biol. Med. 93, I46.

Nisonoff, A. \& Thorbecke, G. J. (1964). Immunochemistry. Ann. Rev. Biochem. 33, 355. 
NoGUCHI, H. (1926). Comparative studies of herpetomonads and leishmanias. J. exp. Med. 44, 327.

Nossal, G. J. V., Svenberg, A., Ada, G. L. \& Austin, C. M. (1964). Single cell studies on i9S antibody production. J. exp. Med. 119, 485 .

Onoue, K., YAGI, Y., Grossberg, A. \& Pressman, D. (1965). Number of binding sites of rabbit macroglobin antibody and its subunits. Immunochemistry 2, 40I.

PotTer, M., Apella, E. \& Geisser, S. (I965). Variation in the heavy polypeptide chain structure of gamma myclomaimmunoglobins from an inbred strain of mice and a hypothesis as to their origin. J. molec. Biol. 14, 36I.

Roholt, O. A., Onoue, K. \& Pressman, D. (1964). Specific combination of $\mathrm{H}$ and L chains of rabbit gamma globulins. Proc. natn. Acad. Sci., U.S.A. 51, 173.

Roholt, O. A., Radzimski, G. \& Pressman, D. (1963). Antibody combining site: the B polypeptide chain. Science, N.Y. 141, 726.

SeHON, A. (I959). Different types of antibodies produced by allergic individuals depending on route of immunization. In Mechanisms of Antibody Formation: Symposium Proceedings. New York: Academic Press.

SVEHAG, S. \& MANDEL, B. (1964). The formation and properties of poliovirus neutralization antibody. J. exp. Med. 119, I.

Titani, K. \& PUTNAM, F. W. (1965). Immunoglobin structure: amino and carboxyl terminal peptides of Type I Bence Jones protein. Science, N.Y. 147, 1304.

UCHITEL, Y. \& KHASMAN, E. L. (I965). On the mechanism of adjuvant action of nonspecific stimulators of antibody formation. J. Immunol. 94, 492.

UHR, J. W. (1964). The heterogeneity of the immune response. Science, N.Y. 147, 457.

Uhr, J. W. \& FinkelsteIN, M. S. (I963). Antibody formation. J. exp. Med. 117, 457.

VITETTA, E. S. \& GuTtMan, H. N. (I967). Immunological relationships among the lower tryponosomatidae. J. gen. Microbiol. 48, 45.

WhITNEY, P. L. \& TANFORD, C. (1965). Recovery of specific activity after complete unfolding and reduction of an antibody fragment. Proc. natn. Acad. Sci., U.S.A. 53, 524. 